\title{
Yüzeysel Sularda Pestisit Kalıntısının Araştırılması Çalışma Örneği; Alanya Alara Çayı
}

\author{
Hasan Koçyiğit ${ }^{1 *} \oplus$, Firdevs Sinanoğlu²® \\ ${ }^{1}$ Aksaray Üniversitesi, Mühendislik Fakültesi, Çevre Mühendisliği Bölümü, 68100, Aksaray. \\ ${ }^{2}$ Aksaray Üniversitesi, Fen Bilimleri Enstitüsü, 68100, Aksaray.

\section{Özet}

Günümüzde sanayileșmenin ve teknolojinin gelișmesi hayatı kolaylaștırırken diğer taraftan çevre kirliliği sebebiyle kullanılabilir su kaynaklarının azalmasına sebep olmaktadır. Sanayileşmenin ve teknolojinin en önemli çevre kirleticilerden biri de tarımsal amaçlı kullanılan pestisitlerdir. Modern tarımın vazgeçilmezi olan pestisitler endüstriyel, evsel vb. olmak üzere birçok alanda kullanılmaktadırlar. Bu çalışmada Alanya ve çevresinin en önemli su kaynă̆l olan Alara Çayı sularında pestisit kalıntısının araștırılması amaçlanmıștır. Yöredeki tarım faaliyetlerinin yoğunluğu pestisit kalıntısının araștırılması açısından oldukça önemlidir. Bu amaçla Alara Çayı üzerinde 4 adet numune alma noktası belirlenmiştir. Bu noktalardan yağışl ve kurak mevsimleri temsil edecek şekilde numuneler alınmıştır. Alınan numunelerde 110 çeşit pestisitin kalıntı seviyesi araştırılmıştır. Bu pestisitlerin seçilmesinde bölgede yetiştirilen yaş sebze ve meyvelerin ihracatında istenen parametreler, Yerüstü Su Kalitesi Yönetmeliği Tablo-4 ve Tablo-5 dikkate alınarak belirlenmiştir. Alınan numuneler Quechers Metoduna göre ekstrakte edilip, LC-MSMS ve GC-MS cihazlarına enjeksiyon ișlemi yapılarak analiz edilmiștir. Analiz çalıșmalarında Tespit ve Tayin Limitleri ile Geri Kazanım çalıșmaları yapılmıștır. Tespit Limitleri (LOD) 0,23 ile 9,67 ppb arasında değişmektedir. Analiz sonuçlarına göre tespit edilen pestisit değerlerinin Tayin Limitlerinden düşük olduğu gözlemlenmiştir.

\section{Investigation of Pesticide Residue Limits in the Surface Water, Case study: Alara Stream in Alanya}

\begin{abstract}
Recently, the development of industrial activities and technologies, on the one hand make the human life easier, on the other hand, it decreases the available water resources due to environmental pollution. One of the most important environmental pollutants, together with the advancing industrialization and technology, is the widely used of pesticides in agricultural activities. Pesticides, which are indispensable in modern agricultural activities, are used in many areas, like industrial, domestic etc. The main objective of this study is to investigate the pesticide residue in the waters of Alara Stream, which is considered the most important water resource and heartland of Alanya and its environs. The intensity of agricultural activities in the region is very important for the investigation of the pesticide residue. For this purpose, 4 sampling points were determined on the Alara Stream. Samples were collected from these points to represent the wet and dry seasons in this area. The residual levels of 110 pesticides were investigated in the samples. During the selection of these pesticides, the desired parameters in the export of fresh vegetables and fruits are taken into consideration. These parameters are given in Table-4 and Table-5 of the Surface Water Quality Regulation. The samples were extracted according to the Quechers Method and analysed by using the LC-MSMS and GC-MS. Detection and Determination Limits and Recovery studies were carried out during the analysis process. The Detection Limits (LOD) range between 0.23 and 9.67 ppb. According to the results of the analysis, it was observed that the determined pesticide values were lower than these determination limits.
\end{abstract}

$\underline{\text { Keywords }}$

Alara Stream, LC-MSMS, Pesticide, Quechers Method, Surface Water

\section{Giriş}

Alara Çayı, 31,2 m³/s debiye sahip, $82 \mathrm{~km}$ uzunluğunda ve 293 hektar yüzey alanı ile Türkiye'nin güneyinde bulunan Antalya havzası içerisinde yer almakta olup suları Akdeniz'e dökülmektedir. Alara Çayı'nda tarımsal faaliyetlerden kaynaklan kirleticiler ile tarımsal amaçlı su kullanımından dolayı yayılı kirlilik söz konusudur (TÜBİTAK 2013). Alara Çayı'nın bulunduğu Antalya havzası, Türkiye'deki su toplama havzaları içerisinde ortalama yıllık verimi $24,2 \mathrm{~L} / \mathrm{s} / \mathrm{km}^{2}$ olarak en büyük havzadır (Altınbilek vd. 2002). Alara Çayı'nın bulunduğu Antalya İli Alanya İlçesi turizm ve tarım sektörlerinde Türkiye'nin önde gelen merkezlerinden biridir. 
Antalya ilinde gübre kullanımı Türkiye ortalaması ve bazı Avrupa Birliği ülkelerinden daha fazladır. Tarımsal ilaç kullanımı ise Türkiye ortalamasının yaklaşık 8 katıdır (Altınbilek vd. 2002). Tarımsal ilaç olarak pestisit kullanımı 1950'lerden beri aktif bir şekilde yaygınlaşmıştır. Tarımsal amaçlı kullanılan pestisitlerin su kalitesi üzerinde büyük etkisi vardır. Bölgenin tarımın yanında turizm bakımından da zengin olmasından dolayı su kaynaklarının kalitesi daha büyük önem taşımaktadır.

Pestisitlerin başlıca kullanım alanları; tarımsal üretim, bahçecilik, balık yetiştiriciliği, çim gerektiren spor tesisleri (golf sahaları, futbol sahaları), süs amaçlı bölgelerde (parklar, bahçeler, oyun alanları), tütsüleme ve kereste korumacılığı, endüstriyel böcek kontrolü, inşaat (duvar kağıdı yapıştırıcıları, boyalar, sıvacılık vb.), ev ve bahçeler, deniz böcek kontrolü, sucul böcek kontrolü, gıda saklanması, hayvancılık, toplum hijyeni, böcek kontrolü ve beşeri ilaç olarak kullanımıdır (Güler ve Çobanoğlu 1997). Dünyada tüketilen pestisitlerin çoğu, tarım sektöründe, sebze ve meyve üretiminde, zararlılarla mücadelede kullanılmaktadır (Tekbaş vd. 2010).

Mevcut tarım alanlarından daha yüksek verim alınması amacıyla pestisitler farklı alanlarda kullanılmakla birlikte tarımsal üretimde yüksek verim elde etmek için geliştirilmiş ve genellikle tarımda sentetik pestisit kullanımı istikrarlı bir şekilde artmaktadır (Katip 2019; Demirci 2013). Dünya pestisit kullanımı 2011-2016 döneminde yıllık ortalama \%5 büyüme gösterdiği ve Türkiye'nin de halen büyüme trendi içerisinde olduğu ve doygunluğa ulaşmadığı görülmektedir (Chakravarty 2014; Durdu 2018). Dünyada pestisit tüketimi yıllık 3,5 milyon ton iken ülkemizde ruhsatlı yaklaşık 6000 preparat bulunmakta ve bunların yıllık tüketimi yaklaşık 45000 tondur (Durmuşoğlu ve Güngör 2015). Türkiye'de pestisit kullanımı 1,3 kg/ha olduğu tahmin edilmektedir (Burçak 2014). Pestisit pazarında ki büyümeyi etkileyen en önemli faktörler arasında artan nüfus başta olmak üzere, zararlılar da gelişen pestisit dirençleri, kirlenme sonucu ekilebilir tarım alanlarında kalitenin düşmesi ve iklim değişiklikleri gelmektedir. Kalıcı organik sınıfında yer alan pestisitler pek çok gelişmiş ülkede yasaklanmış olmasına rağmen, gelişmekte olan ülkelerde ise kullanımları hala devam etmektedir. Daha az kalıcı fakat daha toksik olarak tanımlanan DDT'den daha zararlı pestisitler bile hala gelişmekte olan ülkelerde yetersiz düzenlemelerden dolayı kullanılmakta, insanlara ve canlılara zarar vermektedir (Wesseling 2005).

Gıdaların üretimi, tüketimi, depolanmaları esnasında gıdalara zarar veren canlıları uzaklaştırmak veya yok etmek, bunlara ilave olarak bitkilerin büyümesini düzenlemek amacıyla da kullanılabilen, gıdalara veya doğrudan insan ve hayvanlara hastalık etmeni taşıyan halk sağlığı zararlılarını kontrol etmek amacıyla da pestisitler kullanılmaktadır (Açar 2015). Tarım zararlılarının kimyasallar yardımı ile öldürülmesi veya uzaklaştırılmasına "kimyasal savaş" adı verilmekte ve bu kimyasal savaşta kullanılan pestisitler, tarım ilacı ya da zirai ilaç olarak da isimlendirilmektedir (Öncüer 1995).

Çevre ve insan sağlığına etkilerinden dolayı pestisit kullanımı ile ilgili projeler üretilip, yasal düzenlemeler getirilmeli ve su kaynakları pestisit kirliliğine karşı izlenmeli ve korunmalıdır. Bu konuyla ilgili Uluslararası Çevre Örgütü (EPA), Dünya Sağlık Örgütü (WHO) ve Dünya Gıda ve Tarım Örgütü (FAO) çeşitli çalışmalar yaparak yasal düzenlemeler geliştirmişlerdir. FAO pestisitleri; "insan veya hayvanlarda oluşabilecek hastalıkları taşıyıcı; gıdaların, tarımsal ürünlerin, ahşap ve ahşap ürünlerinin veya hayvan yemlerinin üretimi, işlenmesi, taşınması, depolanması veya pazarlanması sırasında bu uygulamaları olumsuz etkileyecek her türlü zararlının önlenmesi, yok edilmesi veya kontrol altına alınması amacıyla veya hayvanlar üzerinde veya vücutlarında bulunabilecek zararlıların kontrol altına alınması amacıyla kullanılan maddeler" olarak tanımlamıştır (FAO, 2003). Pestisitler; etkiledikleri canlı gruplarına, zehirlilik derecesine, kimyasal ve fiziksel yapılarına göre değişik şekillerde sınıflandırılmaktadırlar. Kimyasal yapılarına göre organoklorürlü pestisitler, organofosforlu pestisitler, karbamatlı pestisitler, herbisit asitler, üre herbisitler, triazinler, piretroidler olarak sınıflandırılırlar (Gül 2017). Birçok organik klorlu pestisit ve organik kimyasal kalıcı, organik kirletici olarak sınıflandırılır. Bozulmaya karşı dirençli olan organik kirletici olarak sınıflandırılan organik klorlu pestisit ve organik kimyasal kalıcı pestisitler ise aynı zamanda küresel olarak yayılabilmektedir (Weber ve Geoerke 2003; Tanabe 2004). Kalıcı organik kirleticiler içinde en fazla tanınan pestisitler; aldrin, klordan, DDT ve türevleri, dieldrin/endrin, heptaklor, mirex ve toksafendir.

Kimyasal adı "diklorodifeniltrikloroetan” olan DDT, çevre ve insan maruziyeti açısından en çok bilinen kalıcı organik kirleticilerden birisidir. Y1kım ürünleri olan DDE ve DDD'de DDT gibi toksik maddelerdir (Mastalerz 2005). Türkiye'de yasaklanmasına rağmen yarı uçucu özelliklerinden dolayı atmosferde bulunabilmektedirler. Bu yüzden kullanımından 10-15 yıl sonra bile toprakta kullanılan DDT'nin yarısından fazlası kalmaktadır. Organoklorlu pestisitler sınıfında bulunan Aldrin, Endrin ve Klordan yağda çözünürlükleri oldukça yüksek olmasına rağmen suda oldukça az çözünürler ve bu durum çevrede kalıcılıklarını arttırmaktadır (Agarwal 2009). Yapılan araştırmalar sonucu bazı organoklorlu pestisitlerin toprağa tatbik edilmesi halinde \%50'den fazlasının 15-16 yıl toprakta kalabileceği tespit edilmiştir (Kurutaş ve Kılınç 2003).

T.C. Gıda, Tarım ve Hayvancılık Bakanlığı tarafından yürütülen Bitki Sağlığı Uygulamaları ve Kontrolü Projesi kapsamında güvenilir gıdanın sağlanması, taze sebze ve meyvede ihracat ve iç tüketimde yaşanan kalıntı sorununun çözülmesi, daha az ve bilinçli zirai ilaç kullanılması, çevre ve insan sağlığı ile fauna ve floranın korunması amacıyla 2006 yılından beri çeşitli düzenlemeler yapılmıştır. Entegre Mücadele, Entegre ve Kontrollü Ürün Yönetimi ve hasat öncesi pestisit kalıntı izleme çalışmalarına önem verilmiş, zirai ilaçların uçakla kullanımı yasaklanmış, bitkisel üretimde kullanılan zirai ilaçların kayıt altına alınması ve izlenebilirliği sağlanmış, zirai ilaçların reçeteli satışı ve uygulayıcıların sertifikalandırılması için yasal düzenlemeler getirilmiştir (URL-1 2018). 
Bu çalışmada, turizm bölgesi olan ve son zamanlarda tarıma olan yönelişin arttığı Alanya ve çevresinde bulunan ve bölgenin önemli bir akarsuyu olan Alara Çayı'nda pestisit kalıntısının araştırılması amaçlanmıştır. Analizlerde daha az kimyasalın kullanıldığg, ekstraksiyonun daha kolay yapıldığı ve eş zamanlı olarak GC-MS ve LC-MSMS cihazlarına enjeksiyonun yapılabildiği Quechers metodu tercih edilmiştir.

\section{Materyal ve Yöntem}

\subsection{Numune Alma}

Alara Çayı'nda pestisit tayini yapmak amacıyla sebze ve meyve üretiminde özellikle tarım ilaçlarının kullanıldığ ilkbahar ayları (Şubat, Nisan) ve haziran ayında numune alma işlemi gerçekleştirilmiştir. $82 \mathrm{~km}$ uzunluğundaki çayın tamamını temsil edebilmesi için 4 farklı noktadan Niskin Tipi örnekleyici ile numuneler alınmıştır. Numune alma noktaları/istasyonlarının uydu görüntüleri Şekil 1'de ve WGS 84 koordinat sistemi ile belirlenen koordinatları ise Tablo 1'de verilmektedir. Numuneler, TS ISO 5667-6'ya göre kıyıdan $1 \mathrm{~m}$ uzaktan ve su yüzeyinin 25-50 cm altından alınmıştır. TS EN ISO 5667-3'e göre numuneler plastik kaplarda, soğuk zincirle en kısa sürede laboratuvara taşınmıştır. Laboratuvara taşınan numuneler, $4 \pm 2{ }^{\circ} \mathrm{C}^{\prime}$ de muhafaza edilerek 3 gün içinde analiz edilmiştir. Ayrıca numune alma yerinde $\mathrm{pH}$, iletkenlik, çözünmüş oksijen ve sıcaklık ölçümleri standart metotlara (SM 2012) göre, WTW Multi 340i multiparamatre ölçüm cihazı ile yapılmıştır.

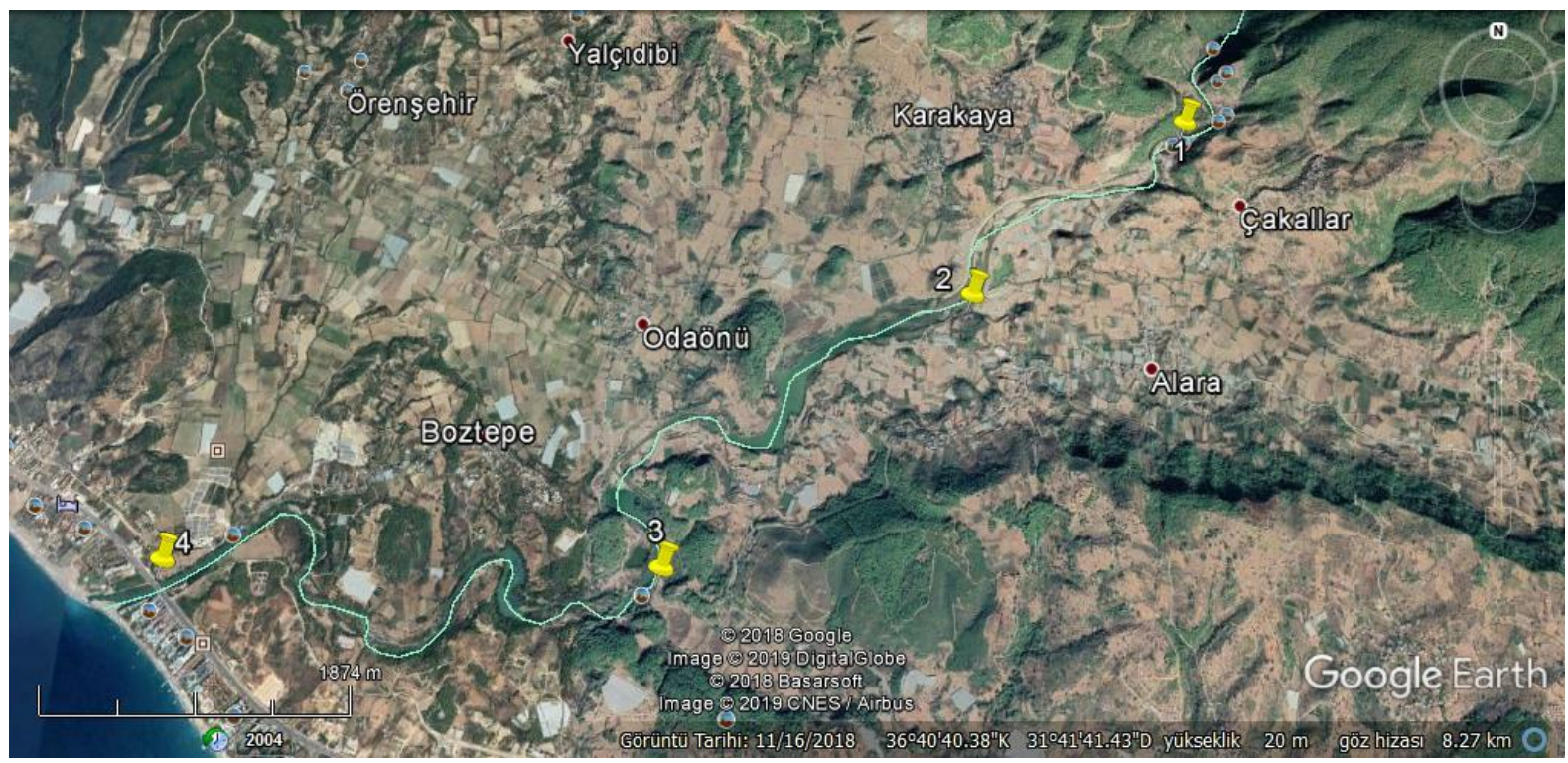

Şekil 1: Alara Çayı numune alma noktaları/istasyonları uydu görüntüsü

Tablo 1: Numune alma noktaları/istasyonları ve koordinatları

\begin{tabular}{|c|c|c|}
\hline \multirow{2}{*}{$\begin{array}{c}\text { İstasyon } \\
\text { Kodu }\end{array}$} & \multicolumn{2}{|c|}{ Numune Alma İstasyonları } \\
\hline & Adı & Koordinatları \\
\hline 1 & Alara Çayı, Alarahan önü, Çakallar Mahallesi & $36^{\circ} 69^{\prime} 21.95 \mathrm{~K} 31^{\circ} 72^{\prime} 30.10 \mathrm{D}$ \\
\hline 2 & Alara Çayı, Alara Mahallesi & $36^{\circ} 68^{\prime} 04.93 \mathrm{~K} 31^{\circ} 70^{\prime} 27.71 \mathrm{D}$ \\
\hline 3 & Alara Çayı, Okurcalar Mahallesi & $36^{\circ} 66^{\prime} 65.14 \mathrm{~K} 31^{\circ} 68^{\prime} 58.33 \mathrm{D}$ \\
\hline 4 & Alara Çayı, denize dökülme noktası, Alara Köprüsü & $36^{\circ} 66^{\prime} 56.60 \mathrm{~K} 31^{\circ} 65^{\prime} 15.17 \mathrm{D}$ \\
\hline
\end{tabular}

\subsection{Pestisitler}

Numunelerde Herbisit, İnsektisit, Akarisit ve Fungusit türleri olan toplam 110 adet pestisit bileşiğinin varlığ araştırılmıştır. Numuneler Quechers Metoduna (AOAC Official Method 2007.01) göre ekstrakte edilip 110 pestisit bileşiğinden 84 tanesi LC-MSMS cihazına 26 tanesi GC-MS cihazına okutulmuştur. Bu pestisitlerin seçilmesinde bölgede yetiştirilen yaş sebze ve meyvelerin ihracatında istenen parametreler ve 10.08.2016 tarihli ve 29797 sayılı yönetmelikle revize olan Yerüstü Su Kalitesi Yönetmeliği dikkate alınmıştır. 
Pestisit analizleri AOAC Official Method 2007.01 Quechers metoduna göre yapılmıştır. Normalde gıda analizleri için kullanılan bu metot, yüzeysel suların analizi için uyarlanmıştır. Metotta sadece matris kısmı değiştirilmiş, geri kalan tüm işlem basamakları aynen uygulanmıştır. Tespit ve tayin limitleri belirlenmiş, 50 ppb'de geri kazanım çalışması yapılarak metodun performansı kontrol edilmiştir. Analizlerde 0.1, 1, 5, 10 ml'lik otomatik pipetler, Bandelin Sonorex RK100 Ultrasonik Banyo, Nüve NF 400/400R Santrifüj, Agilent LC-MSMS ve Agilent GC-MSD cihazları kullanılmıştır.

\subsubsection{Numunelerin Deneye Hazırlanması ve Ekstraksiyon İşlemi}

Bu çalışmada Quechers metodu uygulanmıştır (Lehotay 2007). Bu metoda göre numunelerin ekstraksiyonu iki aşamada gerçekleşmektedir.

1. Aşama: İyice çalkalanan numunelerden $15^{\prime}$ er $\mathrm{ml}, 50 \mathrm{ml}$ 'lik santrifüj tüplerine alınmıştır. Her birinin üzerine $15 \mathrm{ml}$

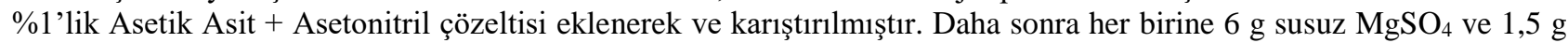
susuz Sodyum Asetat tuzu eklendi ve santrifüjde $5 \mathrm{dk} 4000 \mathrm{rpm}$ 'de karıştırılmıştır. Santrifüj işlemi sonunda fazların ayrıldı̆̆ı görülmüştür.

2. Aşama: 15 ml' lik santrifüj tüpüne $0,4 \mathrm{~g}$ PSA ve 1,2 g susuz magnezyum sülfat konulmuştur. Bu tüplerden numune sayısı kadar hazırlanmıştır. 1. aşama sonunda fazları ayrılan numunelerden 8 'er ml, hazırlanarak santrifüj tüplerine eklendi ve santrifüjde 5 dk 4000 rpm'de karıştırılmıştır.

\subsubsection{Kalibrasyon Eğrisinin Hazırlanması}

LC-MSMS için 100 ppm konsantrasyona sahip 7 ayrı karışım içeren sertifikalı referans malzemelerle, çözücü olarak asetonitril kullanılarak hazırlanan 100 ppb'lik ara stok çözeltiden 5 ppb standart için $50 \mu 1,10$ ppb standart için $100 \mu 1$ ve 25 ppb standart için $250 \mu \mathrm{l}$ çekilerek viallere konulmuştur. 1ppm'lik ara stok çözeltiden 50 ppb standart için $50 \mu 1,100$ ppb standart için $100 \mu \mathrm{l}$ ve 200 ppb standart için $200 \mu \mathrm{l}$ çekilerek viallere konulmuştur. Her bir vial üzerine toplamda 500 $\mu 1$ olacak şekilde asetonitril eklenmiştir. Daha sonra her bir viale $500 \mu \mathrm{l}$ blank konulmuştur. Böylece 5, 10, 25, 50, 100, 200 ppblik standart seri hazırlanmıştır. Standartlar LC-MSMS cihazına yerleştirilip okutularak, lineer kalibrasyon eğrisi çizilmiştir.

GC-MS için 100 ppm konsantrasyona sahip 1 mix sertifikalı referans malzemelerle, çözücü olarak aseton kullanılarak hazırlanan 100 ppb'lik ara stok çözeltiden 2 ppb standart için $20 \mu 1,5$ ppb standart için $50 \mu 1,10$ ppb standart için $100 \mu 1$ ve 25 ppb standart için $250 \mu$ l çekilerek viallere konulmuştur. 1 ppm'lik ara stok çözeltiden 50 ppb standart için $50 \mu 1$, $100 \mathrm{ppb}$ standart için $100 \mu \mathrm{l}$ çekilerek viallere eklenmiştir. Her bir vial üzerine toplamda $500 \mu 1$ olacak şekilde asetonitril eklenmiştir. Daha sonra her bir viale $500 \mu \mathrm{l}$ blank konulmuştur. Böylece 2, 5, 10, 25, 50, 100 ppblik standart seri hazırlanmıştır. Standartlar GC-MS cihazına yerleştirilip okutularak, lineer kalibrasyon eğrisi çizilmiştir.

\subsection{Quechers Metot}

Quechers adını "hızlı, kolay, ucuz, etkili, sağlam ve güvenilir” anlamına gelen "Quick, Easy, Cheap, Effective, Rugged, Safe" kelimelerinden almaktadır (Lehotay 2007). Quechers Metot Steven J. Lehotay ve Michelangelo Anastassiades tarafından geliştirilmiş ve 2003 yılında yayınlanmıştır. Quechers Metodu yayınlandığı yıllarda Avrupa'da en yaygın kullanılan metoda göre; \%95 solvent tasarrufu, \%95 sarf malzeme maliyeti tasarrufu, \%90 zaman tasarrufu sağlamıştır. $\mathrm{Bu}$ metot çok sayıda pestisitin ekstraksiyonunu sağlamaktadır. Çok farklı matrislerde kullanılabilmektedir. Ekstraktların eş zamanlı olarak hem GC/MS hem LC/MS/MS sistemlerine uygun olması nedeniyle yüksek seçicilik ve hassasiyet sağlamaktadır. Metodun modifikasyonlara karşı esnek ve sağlam olması farklı koşullarda uygulanmasını sağlamaktadır (Açar 2015).

$\mathrm{Su}$ ve sedimentteki pestisit kalıntılarının analizi için Quechers metodunun değerlendirilmesine yönelik yapılan bir çalışmada Atrazin, Fipronil, Endosülfan Alfa ve Endosülfan Beta pestisitlerine bakılmıştır. Metot doğruluk, spesifiklik, doğrusallık, tayin ve tespit limitleri açısından valide edilmiştir. Suda farklı pestisit konsantrasyonları için elde edilen geri kazanım \%63 ile \%116 arasında değişmekte olup relatif standart sapması \%12'nin altında, tespit limiti ise 0,003 mg/L bulunmuştur (Brondi vd. 2011). Bu çalışmada da Atrazin, Endosülfan Alfa ve Endosülfan Beta bakılan pestisitler arasındadır ve 10 ile $50 \mu \mathrm{g} / \mathrm{L}$ 'de yapılan çalışmalarda geri kazanım \%109 ile \%80 arasında değişmekle birlikte relatif standart sapma \%16,6'nın altında kalmaktadır. Tespit limiti ise $0,39 \mu \mathrm{g} / \mathrm{L}$ ile 4,43 $\mu \mathrm{g} / \mathrm{L}$ arasında değişmektedir.

\section{4. Ölçüm Limitleri (LOD ve LOQ)}

Tespit limiti (LOD), metodun laboratuvar koşullarında örnekteki varlığını tespit edebileceği ancak kesin miktarını ölçemediği en düşük konsantrasyonudur. Başka bir ifade ile minimum tespit edilebilir değerdir. Tayin limiti (LOQ) ise miktarsal olarak tayin edilebilen en düşük konsantrasyondur. Başka bir ifadeyle kabul edilebilir performansla en düşük konsantrasyon seviyesidir. EURACHEM rehberinde ölçüm limitlerinin en basit hesaplama formülleri (1)'de verilmiştir (Eurachem 2014). 
$\mathrm{LOD}=3 \mathrm{~S}$

LOQ $=10 \mathrm{~S}$ (S: 10 tekrarlı blank analizinin standart sapmasını ifade eder)

SANTE'ye göre ise ölçüm limiti (LOQ) metot performans kriterlerinin (\%70-120 geri kazanım, $\leq \% 20$ RSD) sağlandığ1 en düşük konsantrasyondur. Performans kriterlerinin sağlanamadığı durumlarda, daha yüksek bir değer için 10 tekrarlı çalışma yapılır. Performans kriterlerinin sağlandı̆̆ı değer ölçüm limitidir (EC 2016).

Bu çalışmada 10 ppb konsantrasyonunda hazırlanan standartlarda 10 tekrarlı analiz yapılmış, her bir pestisit için $\mathrm{X}_{\text {ort }}$, $\mathrm{S}, \%$ R, \%RSD, LOD ve LOQ değerleri hesaplanmıştır. Performans kriterlerinin sağlanamadığı bileşikler için ayrıca değer belirlenip tekrarlanabilirlik çalışması yapılmamıştır. Bunun yerine, ilgili bileşikler için 10S değeri LOQ kabul edilmiştir. $\mathrm{X}_{\text {ort }}$ ve S değerleri Excel formüller, \%R ve \% RSD değerleri (2) ve (3)'deki eşitliklerle hesaplanmıştır.
$\% \mathrm{R}=\left(\mathrm{X}_{\mathrm{or}} / \mathrm{X}_{\mathrm{std}}\right) \times 100$
$\% \mathrm{RSD}=\left(\mathrm{S} / \mathrm{X}_{\text {ort }}\right) \times 100$
$\% \mathrm{R}$ : Tekrarlanabilirliğin geri kazanımı
\%RSD: Rölatif standart sapma
$\mathrm{X}_{\text {ort }}$ : Tekrarlanabilirliğin ortalaması
$\mathrm{X}_{\text {std }}$ : Standardın konsantrasyonu
S : Tekrarlanabilirliğin standart sapması

\subsection{Geri Kazanım}

Geri kazanım, numuneye değeri bilinen konsantrasyonda standart spike edilerek, standardın geri kazanılması çalışmasıdır. Standart eklenmiş numune değerinden numunenin kendi değerinin çıkarılmasıyla bulunmaktadır. Bu değer eklenen standart konsantrasyonu ile oranlanınca \% cinsinden geri kazanım değeri bulunur. Bu işlemin formülü (4)'de verilmiştir.

$$
\begin{aligned}
& \% \mathrm{R}=\left[\left(\mathrm{X}_{\text {spike }}-\mathrm{X}_{\text {num }}\right) / \mathrm{X}_{\text {std }}\right] \times 100 \\
& \% \mathrm{R}: \text { Geri Kazanım } \\
& \mathrm{X}_{\text {spike }}: \text { Standart eklenmiş numunenin konsantrasyonu } \\
& \mathrm{X}_{\text {num }}: \text { Numunenin konsantrasyonu } \\
& \mathrm{X}_{\text {std }}: \text { Standardın konsantrasyonu }
\end{aligned}
$$

$\mathrm{Bu}$ çalışmada numunelerle birlikte 50 ppb'lik standart eklenmiş numuneler de cihazlara enjekte edilmiştir. Okuma sonucunda 50 ppb kazanılmaya çalışılmıştır. Böylece metodun verifikasyonu sağlanmıştır.

\section{Bulgular ve Tartışma}

\subsection{Fiziksel Parametrelerin Değerlendirilmesi}

Fiziksel parametrelerden olan sıcaklık, pH, elektriksel iletkenlik (EC) ve çözünmüş oksijen (ÇO) parametreleri numune alma sırasında standart metotlara göre yerinde ölçülmüştür. Şubat, nisan ve haziran aylarında gerçekleştirilen ölçümlerde

\begin{tabular}{|c|c|c|c|c|c|c|c|c|c|c|c|c|}
\hline \multirow{2}{*}{$\begin{array}{l}\text { İst. } \\
\text { kodu }\end{array}$} & \multicolumn{3}{|c|}{$\begin{array}{c}\text { Sicaklık, }{ }^{0} \mathrm{C} \\
\pm \text { Sapma* }\end{array}$} & \multicolumn{3}{|c|}{$\begin{array}{c}\text { pH } \\
\pm \text { Sapma* }\end{array}$} & \multicolumn{3}{|c|}{$\begin{array}{l}\text { ÇO, mg/L } \\
\pm \text { Sapma* }\end{array}$} & \multicolumn{3}{|c|}{$\begin{array}{c}\text { EC, } \mu \mathrm{S} / \mathrm{cm} \\
\pm \text { Sapma* }^{*}\end{array}$} \\
\hline & Şub. & Nis. & Haz. & Şub. & Nis. & Haz. & Şub. & Nis. & Haz. & Şub. & Nis. & Haz. \\
\hline 1 & $\begin{array}{c}14,7 \\
\pm 0,01 \\
\end{array}$ & $\begin{array}{c}16,4 \\
\pm 0,01 \\
\end{array}$ & $\begin{array}{c}18,2 \\
\pm 0,01 \\
\end{array}$ & $\begin{array}{c}8,28 \\
\pm 0,01 \\
\end{array}$ & $\begin{array}{r}8,26 \\
\pm 0,01 \\
\end{array}$ & $\begin{array}{c}8,28 \\
\pm 0,01 \\
\end{array}$ & $\begin{array}{c}8,73 \\
\pm 0,009 \\
\end{array}$ & $\begin{array}{c}8,81 \\
\pm 0,009 \\
\end{array}$ & $\begin{array}{c}8,95 \\
\pm 0,009 \\
\end{array}$ & $\begin{array}{c}378 \\
\pm 1,89 \\
\end{array}$ & $\begin{array}{c}356 \\
\pm 1,78 \\
\end{array}$ & $\begin{array}{c}289 \\
\pm 1,45 \\
\end{array}$ \\
\hline 2 & $\begin{array}{c}15,6 \\
\pm 0,01 \\
\end{array}$ & $\begin{array}{c}17,6 \\
\pm 0,01 \\
\end{array}$ & $\begin{array}{c}19,3 \\
\pm 0,01 \\
\end{array}$ & $\begin{array}{c}8,21 \\
\pm 0,01 \\
\end{array}$ & $\begin{array}{c}8,23 \\
\pm 0,01 \\
\end{array}$ & $\begin{array}{c}8,23 \\
\pm 0,01 \\
\end{array}$ & $\begin{array}{c}8,40 \\
\pm 0,008 \\
\end{array}$ & $\begin{array}{c}8,34 \\
\pm 0,008 \\
\end{array}$ & $\begin{array}{c}8,35 \\
\pm 0,008 \\
\end{array}$ & $\begin{array}{c}374 \\
\pm 1,87 \\
\end{array}$ & $\begin{array}{c}357 \\
\pm 1,79 \\
\end{array}$ & $\begin{array}{c}298 \\
\pm 1,49 \\
\end{array}$ \\
\hline 3 & $\begin{array}{c}14,2 \\
\pm 0,01 \\
\end{array}$ & $\begin{array}{c}17,3 \\
\pm 0,01 \\
\end{array}$ & $\begin{array}{c}20,2 \\
\pm 0,01 \\
\end{array}$ & $\begin{array}{r}8,30 \\
\pm 0,01 \\
\end{array}$ & $\begin{array}{r}8,29 \\
\pm 0,01 \\
\end{array}$ & $\begin{array}{r}8,30 \\
\pm 0,01 \\
\end{array}$ & $\begin{array}{c}8,60 \\
\pm 0,009 \\
\end{array}$ & $\begin{array}{c}8,42 \\
\pm 0,008 \\
\end{array}$ & $\begin{array}{c}8,38 \\
\pm 0,008 \\
\end{array}$ & $\begin{array}{c}380 \\
\pm 1,90 \\
\end{array}$ & $\begin{array}{c}360 \\
\pm 1,80 \\
\end{array}$ & $\begin{array}{c}294 \\
\pm 1,47 \\
\end{array}$ \\
\hline 4 & $\begin{array}{c}14,3 \\
\pm 0,01 \\
\end{array}$ & $\begin{array}{c}17,8 \\
\pm 0,01 \\
\end{array}$ & $\begin{array}{r}19,0 \\
\pm 0,01 \\
\end{array}$ & $\begin{array}{r}8,33 \\
\pm 0,01 \\
\end{array}$ & $\begin{array}{r}8,32 \\
\pm 0,01 \\
\end{array}$ & $\begin{array}{r}8,35 \\
\pm 0,01 \\
\end{array}$ & $\begin{array}{c}8,57 \\
\pm 0,009 \\
\end{array}$ & $\begin{array}{c}8,45 \\
\pm 0,008 \\
\end{array}$ & $\begin{array}{c}8,33 \\
\pm 0,008 \\
\end{array}$ & $\begin{array}{r}390 \\
\pm 1,95 \\
\end{array}$ & $\begin{array}{c}384 \\
\pm 1,92 \\
\end{array}$ & $\begin{array}{r}339 \\
\pm 1,70 \\
\end{array}$ \\
\hline
\end{tabular}
elde edilen sonuçlar Tablo 2'de verilmiştir. Ölçüm yapılmadan önce cihazın dahili kalibrasyonları ve verifikasyonu gerçekleştirilmiştir. Bu ölçümler Alara Çayı'nın, "Kıta içi su kaynaklarının sınıflarına göre kalite kriterleri”" (Resmi Gazete 2015) ile karşılaştırıldığında 1. sınıf su kalitesine sahip olduğunu göstermektedir.

Tablo 2: Fiziksel parametrelerin ölçüm sonuçları

*Ölçümlerde kullanılan WTW Multi 340i cihazının standart sapması 
pH; şubat, nisan, haziran dönemlerinde bütün noktalarda 8 civarında çıkmıştır. Bu değer suların alkali olduğunu göstermektedir. Bütün dönem ve noktalarda $\mathrm{pH}$ değerleri yönetmeliğe göre "su kalite sinıfları (6-9)" aralığını sağlamaktadır. Elektriksel İletkenlik değerleri tüm dönemlerde 280-400 $\mu \mathrm{S} / \mathrm{cm}$ arasında çıkmıştır. Bütün dönem ve noktalarda EC değerleri "Kıta içi su kaynaklarının sınıflarına göre kalite kriterleri” yönetmeliğine göre "su kalite sınıfları (<400)" standardını sağlayarak "Çok İyi Su” sınıfına girmektedir. Ayrıca üç dönemde de en yüksek EC değerleri çayların denize döküldüğü noktalarda çıkmıştır. Bu da az da olsa tuzlu su karışımı olduğunu göstermektedir. Çözünmüş oksijen değerleri, bütün noktalarda 8-9 mg/L arasında çıkmıștır. Bütün dönem ve noktalarda ÇO değerleri Yönetmeliğe göre "Su kalite sınıfları (>8)" standardını sağlayarak "Çok İyi Su" sınıfına girmektedir. Bu sonuçların kıyaslanmasında "Yerüstü Su Kalitesi Yönetmeliği” Tablo-2, Tablo-4 ve Tablo-5 kullanılmıştır.

\subsection{Pestisitlerin Analiz Sonuçlarının Değerlendirilmesi}

110 adet pestisitin 10 tekrarlı tekrarlanabilirlik çalışmaları yapılarak $\mathrm{X}_{\text {ort }}, \mathrm{S}, \% \mathrm{R}, \% \mathrm{RSD}$, LOD ve LOQ değerleri belirlenmiştir. 10 ppb'de yapılan tekrarlanabilirlik çalışması sonucunda, bakılan tüm pestisit bileşikleri için geri kazanım $\% 70$ ile \%120 arasında çıkmıştır. \%RSD açısından bakıldığında Vinclozolin \%20'den büyük; Chinomethionat, Cypermethrin-delta, Cypermethrin-alfa, Endosulfan-beta, Fenvalerate, Iprodione, Parathion-methyl, Permethrin 1 bileşiklerinin RSD'leri \%20'ye yakın bir değerde çıkmıştır. Dolayısıyla LOQ=10S değeri, 10 ppb'den küçük çıkan pestisitler için genel olarak $\mathrm{LOQ}=10$ denilebilir. Ancak LOQ=10S değeri 10 ppb'den büyük çıkan pestisitler için LOQ $=10 \mathrm{~S}$ alınmalıdır.

Şubat ayında alınan numunelerin analiz sonuçları daha doğru ve güvenilir sonuç verebilmek için bu değerlerin blank ve ACN değerleri ile karşılaştırılmıştır. Numunelere ait değerlerle blank ve ACN değerleri karşılaştırıldığında; Metribuzin'in 1 ve 4 no'lu numunelerde, Simazine'in 1 no'lu numunede, Endosülfan alfa ve Endosülfansülfat'ın 2 no'lu numunelerde varlığından söz edilebilir. Lambda-Cyhalothrin 1 no'lu numunelerde normal dışı yüksek değer çıkmıştır. Bu yüzden bu noktada ilgili pestisit bileşiklerinin varlığından söz edilemez. Elektriksel olaylar ve kolondan çok küçük de olsa hava kabarcığı geçmesi bu gibi durumlara neden olabilmektedir. Önlem olarak, numune okumalarını yaparken, bilinen bir referansla karşılaştırma yapmak güvenirliliği arttıracaktır. Şekil 2'de LC-MSMS, Şekil 3'de ise GC-MS şubat ayına ait kromatogram görüntüleri çalışılan istasyonlar için kod numarası ile verilmiştir.
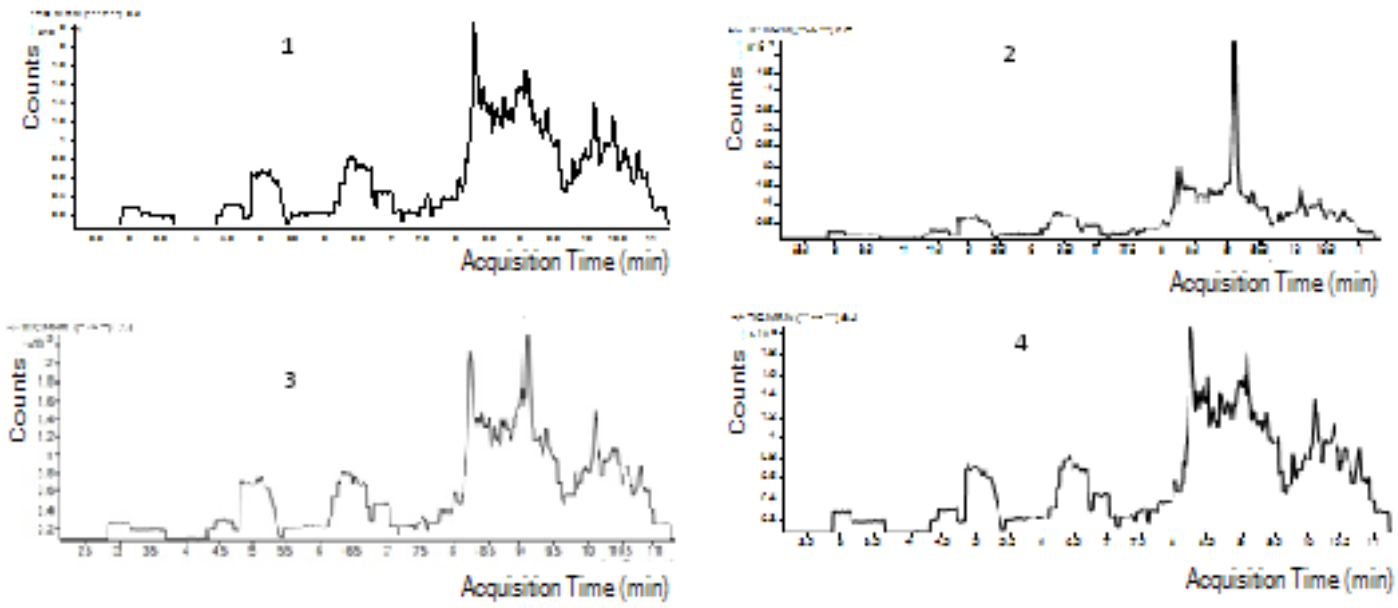

Şekil 2: Şubat ayı LC-MSMS kromatogram görüntüleri 

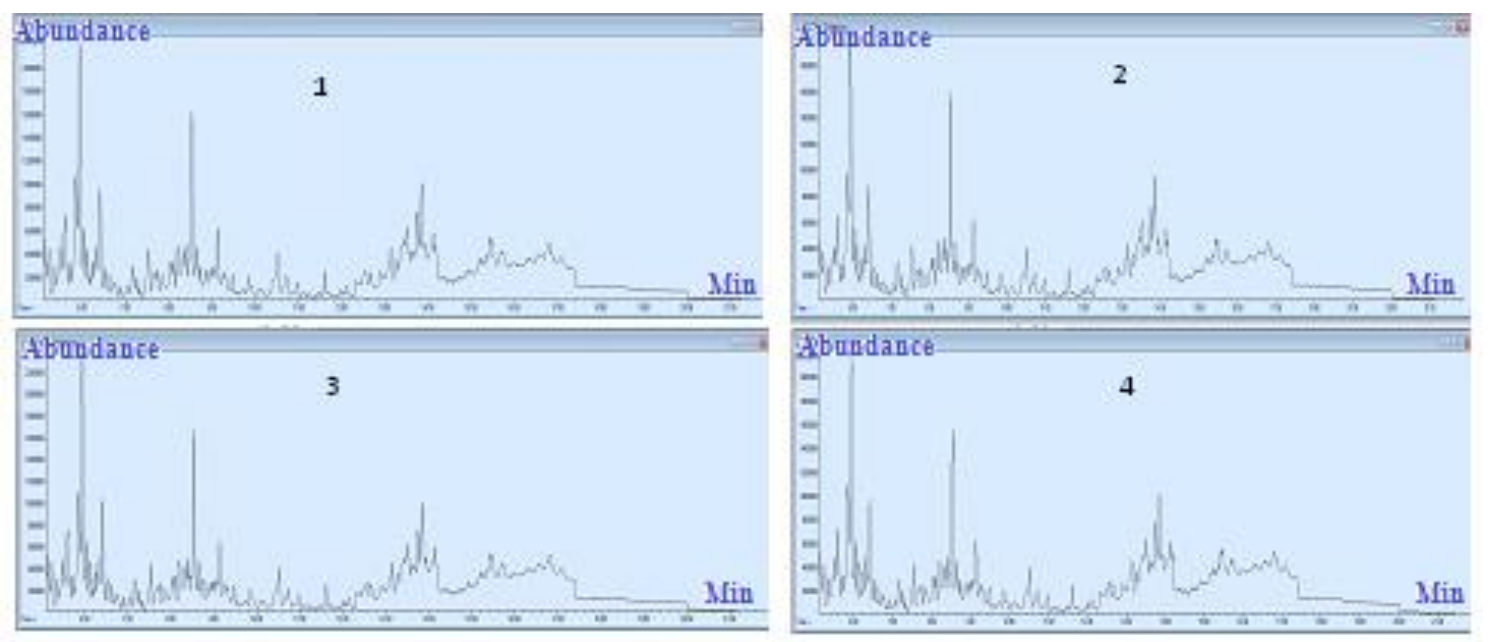

Şekil 3: Şubat ayı GC-MS kromatogram görüntüleri

Nisan ayında, şubat ayında yapılan çalışmalara ek olarak 50 ppb standart ile spike yapılarak geri kazanım değerleri ile de karşılaştırma yapılmıştır. Nisan ayına ait numune okumaları ile blank, ACN okumaları, spike yapılmış numune okumaları ve geri kazanım sonuçlarının karşılaştırılması yapılmıştır. Numune sonuçlarının blank ve ACN sonuçlarından büyükse ve geri kazanım sonuçları \%80-\%120 aralığına giriyorsa bu numunede ilgili pestisit vardır denilebilir. Buna göre Metribuzin'in 2, 3, 4 no'lu numunelerde, Penconazole'un 3 no'lu numunede, Thiophanate-methyl'in 3 no'lu numunede, Procymidone'un 2 no'lu numunede, Permethrin 1, 2, 4 no'lu numunelerde, Parathion-methyl'in 1, 4 no'lu numunelerde, Endosulfan-alpha'nın 1, 2, 3, 4 no'lu numunelerde, Dicofol'un 2, 3 no'lu numunelerde bulunduğu tespit edilmiştir. Şekil 4'de LC-MSMS, Şekil 5'de ise GC-MS nisan ayına ait kromatogram görüntüleri çalışılan istasyonlar için kod numarası ile verilmiştir.
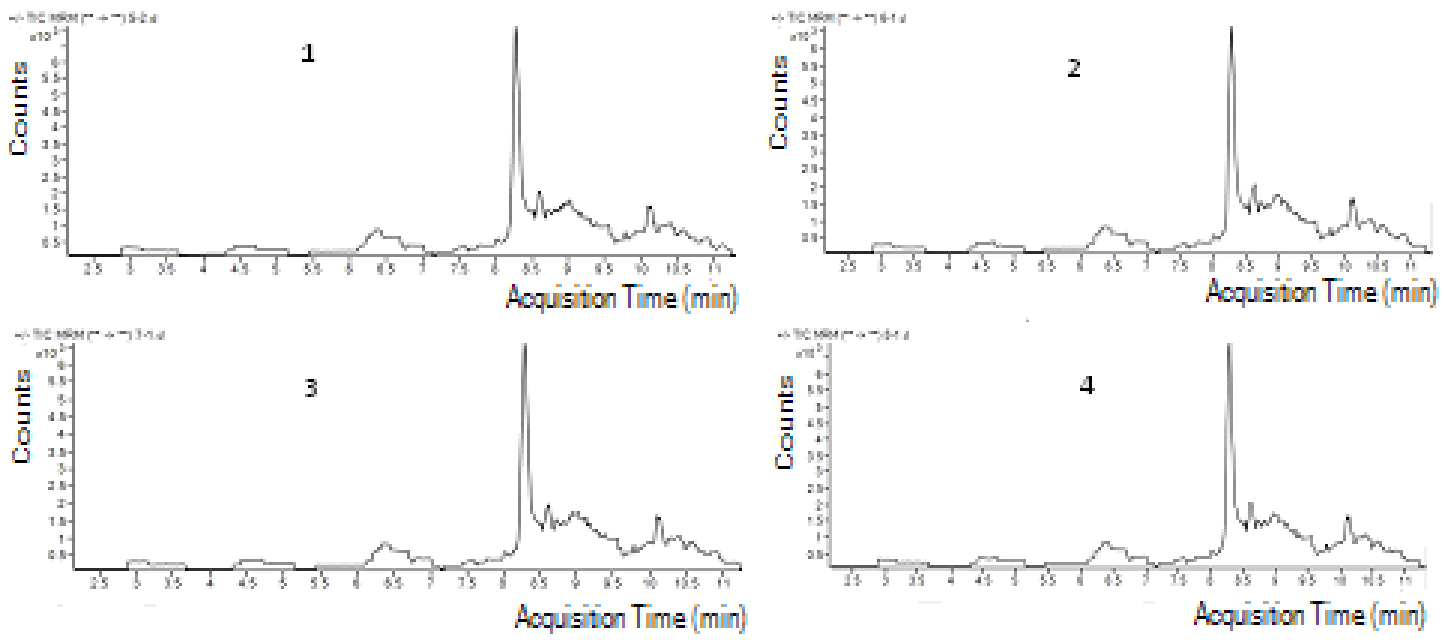

Şekil 4: Nisan ayı LC-MSMS kromatogram görüntüleri 

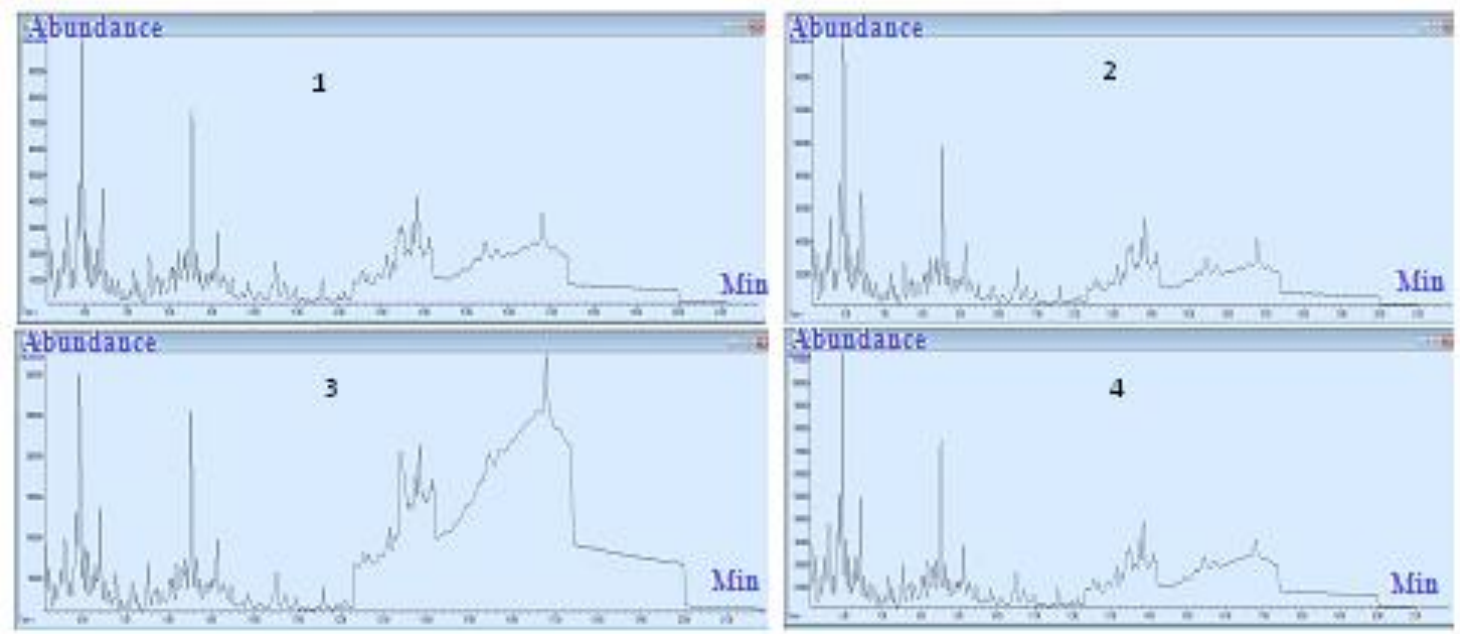

\section{Şekil 5: Nisan ayı GC-MS kromatogram görüntüleri}

Haziran ayına ait numune okumaları ile blank, ACN okumaları, spike yapılmış numune okumaları ve geri kazanım sonuçlarının karşılaştırılması yapılmıştır. Numune sonuçlarının blank ve ACN sonuçlarından büyükse ve geri kazanım sonuçları \%80-\%120 aralığına giriyorsa bu numunede ilgili pestisit vardır denilebilir. Buna göre Chlorfluazurone ve 2, 4 D'in 1 ve 3 no'lu numunelerde, Endosülfan Beta'nın 2 no'lu numunede, Fenarimol'un 1, 2, 3 no'lu numunelerde, Malathion'un 1 ve 4 no'lu numunelerde, Metribuzin'in 3 no'lu numunede, Penconazole'nin 2 no'lu numunede, Permethrin 1'in 4 no'lu numunede, Tetradiphon'un 2 no'lu numunede, Vinclozolin'in 3 no'lu numunelerde bulunduğu tespit edilmiştir. Şekil 6'da LC-MSMS, Şekil 7'de ise GC-MS nisan ayına ait kromatogram görüntüleri çalışılan istasyonlar için kod numarası ile verilmiştir.
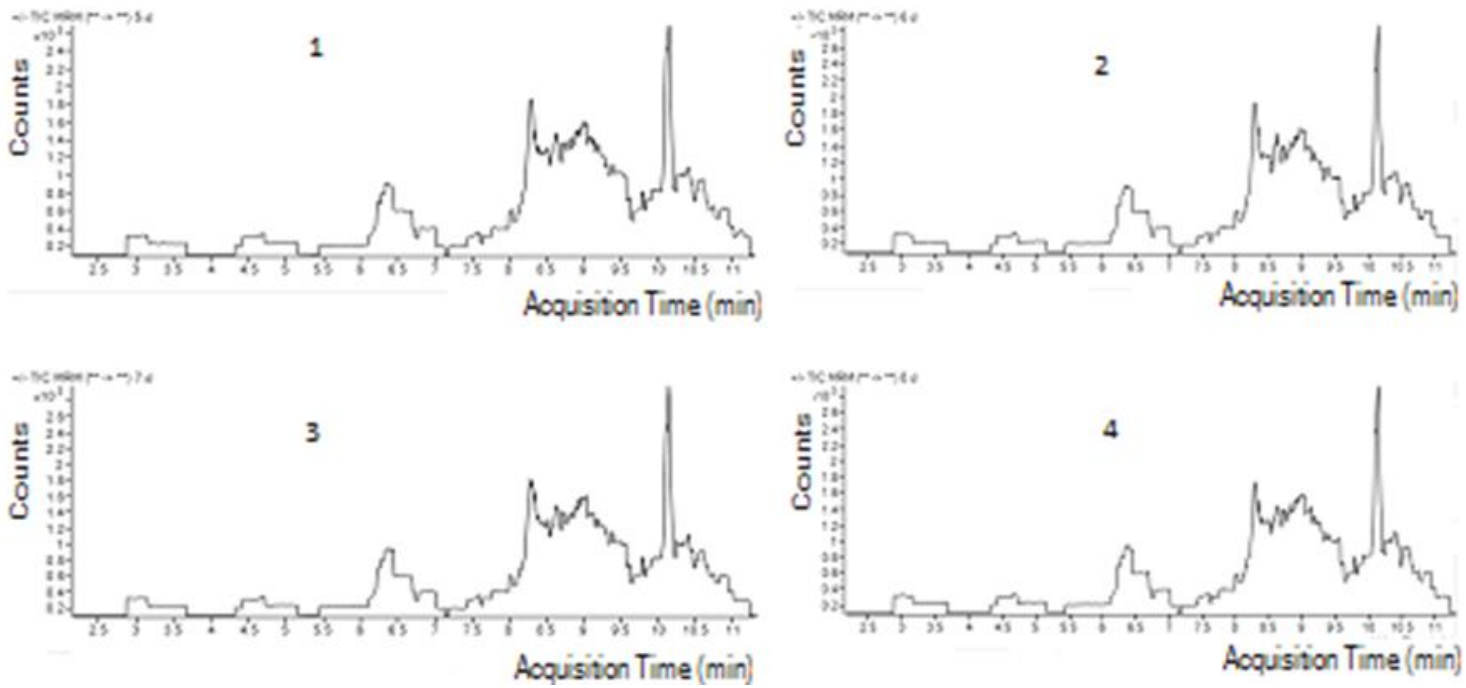

Şekil 6: Haziran ayı LC-MSMS kromatogram görüntüleri 

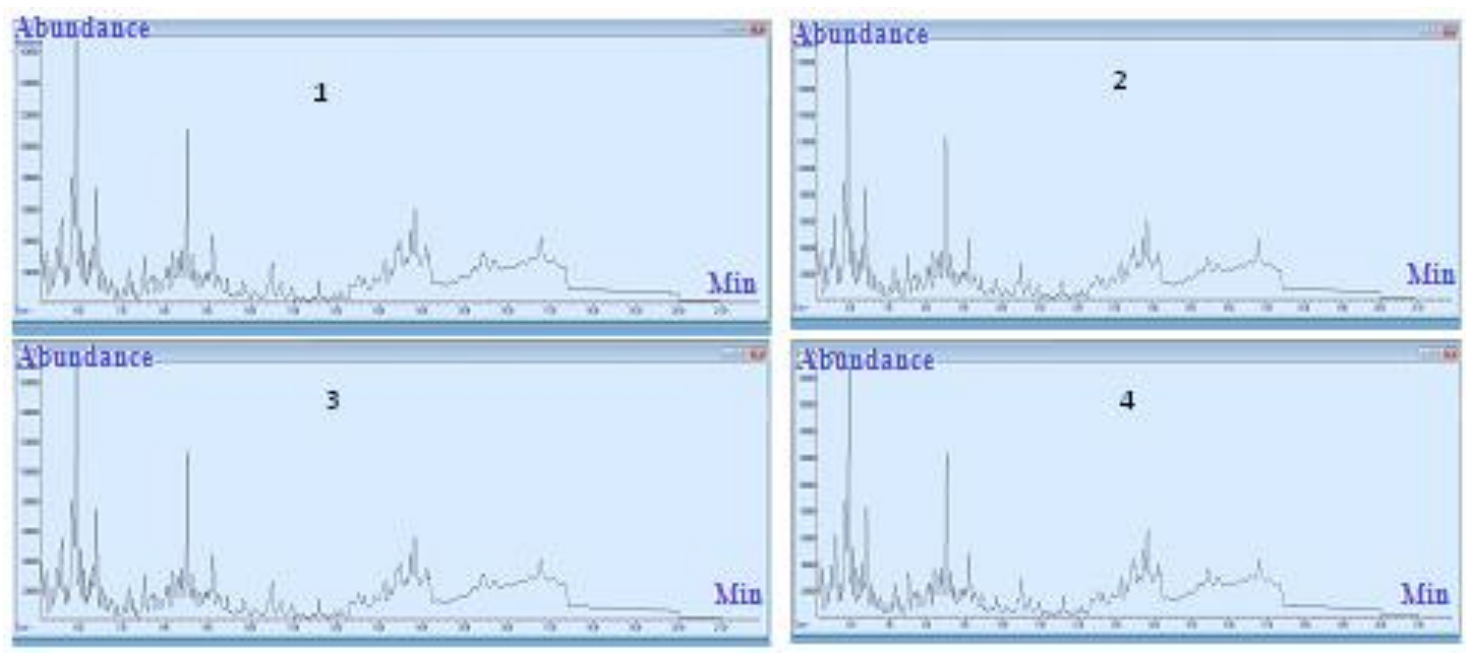

Şekil 7: Haziran ayı GC-MS kromatogram görüntüleri

Yapılan çalışmada tespit edilen pestisitler, sınıfı ve maksimum izin verilebilir çevresel kalite standartları (Resmi Gazete 2015) Şubat ayı Tablo 3'te, nisan ayı Tablo 4'te ve haziran ayı Tablo 5'de verilmiştir.

Tablo 3: Şubat ayında tespit edilen pestisitler

\begin{tabular}{|l|c|c|c|c|}
\hline \multicolumn{1}{|c|}{ Pestisitler } & $\begin{array}{c}\text { İstasyon } \\
\text { kodu }\end{array}$ & Sınıfi & $\begin{array}{c}\text { Sonuç } \pm \text { RSD* } \\
(\mathrm{ppb})\end{array}$ & $\begin{array}{c}\text { Maksimum izin verilebilir } \\
\text { çevresel kalite standardi } \\
\text { (Resmi Gazete 2015) (ppb) }\end{array}$ \\
\hline Cypermethrinalpha & 1 & İnsektisit & $6,74 \pm 1,11$ & 0,0006 \\
\hline Cypermethrinalpha & 4 & İnsektisit & $5,52 \pm 0,91$ & 0,0006 \\
\hline Cypermethrin & 1 & İnsektisit & $7,57 \pm 1,06$ & 0,0006 \\
\hline Cypermethrin & 2 & İnsektisit & $1,98 \pm 0,28$ & 0,0006 \\
\hline Cypermethrin & 3 & İnsektisit & $2,44 \pm 0,34$ & 0,0006 \\
\hline Cypermethrin & 4 & İnsektisit & $5,52 \pm 0,77$ & 0,0006 \\
\hline Deltamethrin & 1 & İnsektisit & $1,35 \pm 0,05$ & - \\
\hline Metribuzin & 1 & Herbisit & $0,82 \pm 0,03$ & - \\
\hline Metribuzin & 3 & Herbisit & $0,48 \pm 0,02$ & - \\
\hline Metribuzin & 4 & Herbisit & $0,78 \pm 0,03$ & 4 \\
\hline Simazine & 1 & Herbisit & $1,35 \pm 0,04$ & - \\
\hline Endosülfan alfa & 2 & İnsektisit & $1,78 \pm 0,09$ & 0,01 (alpha+beta+sulfate) \\
\hline Endosülfan sülfat & 2 & İnsektisit & $1,15 \pm 0,06$ & 0,01 (alpha+beta+sulfate) \\
\hline
\end{tabular}

*16 farklı yüzey suyunda yapılan geri kazanım çalışmaları sonucu elde edilen relatif standart sapma.

Tablo 3'de görüldüğü üzere tespit edilen pestisitlerden Deltamethrin ve Metribuzin, maksimum izin verilebilir çevresel kalite standardı listesinde bulunmamaktadır. İnsektisit türü olan ve klorlu hidro karbonlar sınıfında yer alan Endosülfan Alfa ve Endosülfan Sülfat parametreleri maksimum izin verilebilir çevresel kalite standardı değerinden yüksektir. İnsektisit türü olan Cypermethrin değerleri de izin verilebilir çevresel kalite standardı değerinden yüksektir. 
Tablo 4: Nisan ayında tespit edilen pestisitler

\begin{tabular}{|c|c|c|c|c|}
\hline Pestisitler & $\begin{array}{l}\text { İstasyon } \\
\text { kodu }\end{array}$ & Sinıfi & $\begin{array}{c}\text { Sonuç } \pm \text { RSD } * \\
(\mathrm{ppb})\end{array}$ & $\begin{array}{l}\text { Maksimum izin verilebilir } \\
\text { çevresel kalite standardı } \\
\text { (Resmi Gazete 2015) (ppb) }\end{array}$ \\
\hline Cypermethrinalpha & 1 & İnsektisit & $5,78 \pm 0,95$ & 0,0006 \\
\hline Cypermethrinalpha & 3 & İnsektisit & $7,72 \pm 1,27$ & 0,0006 \\
\hline Cypermethrin & 1 & İnsektisit & $13,37 \pm 1,86$ & 0,0006 \\
\hline Cypermethrin & 2 & İnsektisit & $12,03 \pm 1,68$ & 0,0006 \\
\hline Cypermethrin & 3 & İnsektisit & $11,96 \pm 1,67$ & 0,0006 \\
\hline Deltamethrin & 3 & İnsektisit & $1,32 \pm 0,05$ & - \\
\hline Deltamethrin & 4 & İnsektisit & $1,52 \pm 0,06$ & - \\
\hline Dicofol & 1 & Akarisit & $1,19 \pm 0,06$ & - \\
\hline Dicofol & 2 & Akarisit & $1,63 \pm 0,09$ & - \\
\hline Dicofol & 3 & Akarisit & $1,64 \pm 0,09$ & - \\
\hline Endosülfanalpha & 1 & İnsektisit & $2,59 \pm 0,13$ & 0,01 (alpha+beta+sulfate) \\
\hline Endosülfanalpha & 2 & İnsektisit & $1,71 \pm 0,09$ & 0,01 (alpha+beta+sulfate) \\
\hline Endosülfanalpha & 3 & İnsektisit & $2,23 \pm 0,12$ & 0,01 (alpha+beta+sulfate) \\
\hline Endosülfanalpha & 4 & İnsektisit & $3,63 \pm 0,19$ & 0,01 (alpha+beta+sulfate) \\
\hline Endosülfan sülfat & 2 & İnsektisit & $2,22 \pm 0,11$ & 0,01 (alpha+beta+sulfate) \\
\hline Endosülfan sülfat & 3 & İnsektisit & $2,22 \pm 0,11$ & 0,01 (alpha+beta+sulfate) \\
\hline Malathion & 1 & İnsektisit & $2,11 \pm 0,04$ & 42 \\
\hline Malathion & 2 & İnsektisit & $2,72 \pm 0,05$ & 42 \\
\hline Malathion & 3 & İnsektisit & $1,47 \pm 0,03$ & 42 \\
\hline Malathion & 4 & İnsektisit & $2,05 \pm 0,04$ & 42 \\
\hline Metribuzin & 2 & Herbisit & $0,07 \pm 0,002$ & - \\
\hline Metribuzin & 3 & Herbisit & $0,17 \pm 0,006$ & - \\
\hline Metribuzin & 4 & Herbisit & $0,22 \pm 0,008$ & - \\
\hline Parathion-methyl & 1 & İnsektisit & $3,71 \pm 0,56$ & 2,5 \\
\hline Parathion-methyl & 4 & İnsektisit & $7,14 \pm 1,08$ & 2,5 \\
\hline Penconazole & 3 & Fungusit & $0,84 \pm 0,01$ & 1,9 \\
\hline Permethrin 1 & 1 & İnsektisit & $0,57 \pm 0,09$ & 0,12 \\
\hline Permethrin 1 & 2 & İnsektisit & $3,63 \pm 0,55$ & 0,12 \\
\hline Permethrin 1 & 4 & İnsektisit & $4,49 \pm 0,68$ & 0,12 \\
\hline Procymidone & 2 & Fungusit & $4,14 \pm 0,28$ & 12 \\
\hline Thiophanate-methyl & 3 & Fungusit & $0,16 \pm 0,01$ & 42 \\
\hline
\end{tabular}

*16 farklı yüzey suyunda yapılan geri kazanım çalışmaları sonucu elde edilen relatif standart sapma.

Tablo 4'de görüldüğü üzere Deltamethrin, Metribuzin ve Dicofol, maksimum izin verilebilir çevresel kalite standardı listesinde yoktur. İnsektisit türü olan ve klorlu hidrokarbonlar sınıfında yer alan Endosülfan Alfa, Parathion-methyl, Permethrin 1 ve Cypermethrinile Fungusit türü olan Penconazolemaksimum izin verilebilir çevresel kalite standardı değerinden yüksektir. 
Tablo 5: Haziran ayında tespit edilen pestisitler

\begin{tabular}{|c|c|c|c|c|}
\hline Pestisitler & $\begin{array}{l}\text { İstasyon } \\
\text { kodu }\end{array}$ & Sinıfi & $\begin{array}{c}\text { Sonuç } \pm \text { RSD } * \\
(\mathrm{ppb})\end{array}$ & $\begin{array}{c}\text { Maksimum izin verilebilir } \\
\text { çevresel kalite standardı } \\
\text { (Resmi Gazete 2015) (ppb) }\end{array}$ \\
\hline $2,4 \mathrm{D}$ & 1 & Herbisit & $5,23 \pm 0,09$ & 583 \\
\hline $2,4 \mathrm{D}$ & 3 & Herbisit & $5,50 \pm 0,09$ & 583 \\
\hline Chlorfluazurone & 1 & İnsektisit & $0,59 \pm 0,02$ & - \\
\hline Chlorfluazurone & 3 & İnsektisit & $0,59 \pm 0,02$ & - \\
\hline Deltamethrin & 2 & İnsektisit & $1,37 \pm 0,05$ & - \\
\hline Deltamethrin & 4 & İnsektisit & $1,36 \pm 0,05$ & - \\
\hline Endosülfan beta & 2 & İnsektisit & $8,11 \pm 0,55$ & 0,01 (alpha+beta+sulfate) \\
\hline Fenarimol & 1 & Fungusit & $2,56 \pm 0,16$ & 0,07 \\
\hline Fenarimol & 2 & Fungusit & $3,11 \pm 0,20$ & 0,07 \\
\hline Fenarimol & 3 & Fungusit & $2,07 \pm 0,13$ & 0,07 \\
\hline Malathion & 1 & İnsektisit & $2,46 \pm 0,05$ & 42 \\
\hline Malathion & 4 & İnsektisit & $2,43 \pm 0,04$ & 42 \\
\hline Metribuzin & 3 & Herbisit & $3,37 \pm 0,12$ & - \\
\hline Penconazole & 2 & Fungusit & $3,24 \pm 0,06$ & 1,9 \\
\hline Permethrin 1 & 4 & İnsektisit & $12,07 \pm 1,82$ & 0,12 \\
\hline
\end{tabular}

*16 farklı yüzey suyunda yapılan geri kazanım çalıșmaları sonucu elde edilen relatif standart sapma.

Tablo 5'de görüldüğü üzere Metribuzin, Deltamethrin ve Chlorfluazurone maksimum izin verilebilir çevresel kalite standardı listesinde yoktur. İnsektisit türü olan ve klorlu hidrokarbonlar sınıfında yer alan Endosülfan Beta ve Permethrin 1 ile Fungusit türü olan Fenarimol ve Penconazole maksimum izin verilebilir çevresel kalite standardı değerinden yüksektir.

Alara Çayı'nda tespit edilen pestisit bileşiklerinin bazıları T.C Gıda Tarım ve Hayvancılık Bakanlığı tarafından yayınlanan Yasaklı Aktif Maddeler listesinde bulunmaktadır (URL-2 2018). Tespit edilen pestisit bileşiklerinden yasaklı aktif madde listesinde yer alanlar Tablo 6'da verilmiştir.

Tablo 6: Yasaklı aktif maddeler (URL-2 2018)

\begin{tabular}{|l|c|c|}
\hline Aktif Madde Adı & $\begin{array}{c}\text { İmalat ve İthalatının } \\
\text { Sonlandırılma Tarihi }\end{array}$ & $\begin{array}{c}\text { Kullanımının } \\
\text { Sonlandırılma Tarihi }\end{array}$ \\
\hline Chlorfluazuron & 30.06 .2010 & 31.08 .2011 \\
\hline Dichlofluanid & 01.01 .2009 & 01.01 .2011 \\
\hline Dicofol & 30.06 .2010 & 31.08 .2011 \\
\hline Endosulfan & 01.01 .2009 & 01.01 .2011 \\
\hline Fenarimol & 30.06 .2010 & 31.08 .2011 \\
\hline ParathionMethyl & 31.08 .2009 & 31.08 .2011 \\
\hline Permethrin & 01.01 .2009 & 01.01 .2011 \\
\hline Procymidone & 31.08 .2009 & 31.08 .2011 \\
\hline Simazine & 01.01 .2009 & 01.01 .2011 \\
\hline Tetradifon & 30.06 .2010 & 31.08 .2011 \\
\hline Vinclozolin & 01.01 .2009 & 01.01 .2011 \\
\hline
\end{tabular}

Bu aktif maddeler için Sigma-Aldrich firmasının Güvenlik Bilgi Formları incelendiğinde; Ekolojik Bilgiler başlığı altında Permethrin, Parathion Methyl, Permethriniçin "Sucul ortamda uzun süre kalıcıdır." Tetradifon için "Kendiliğinden doğada kolaylıkla çözülmez.” diğerleri için "Uygun veri yoktur.” ibareleri yer almaktadır (URL-3 2018; Schulz 2001; Villarroel vd. 2009). 


\section{Sonuçlar}

$\mathrm{Bu}$ çalışma, yaş sebze ve meyve yetiştirilmesinde önemli yeri olan Alanya'da bulunan Alara Çayı sularında pestisit kalıntısının belirlenmesi amacıyla yapılmıştır. Alara Çayı'nda fiziksel parametrelerden olan sıcaklık, pH, EC ve ÇO parametreleri, "Yerüstü Su Kalitesi Yönetmeliği”" Tablo-2, Tablo-4 ve Tablo-5'e göre kıyaslandığında "Çok İyi Su" sınıfına girmektedir. "Kıta içi su kaynaklarının sınıflarına göre kalite kriterleri” ile karşılaştırıldığında ise 1. sınıf su kalitesine girmektedir. 4 farklı numune alma noktasında ve farklı 3 dönemde alınan su örnekleri ile yapılan pestisit analizlerinde nisan ve haziran aylarında şubat ayına göre pestisit çeşitliliğinin ve konsantrasyonunun arttığı tespit edilmiştir. Şubat ayında sadece Herbisit ve İnsektisit'e rastlanırken, nisan ve haziran aylarında Akarisit, İnsektisit, Herbisit ve Fungusit türlerine de rastlanmıştır. Bunun nedeni olarak sebze ve meyve için tarımsal ilaçlamanın bu aylarda yapılmasının etkisi olduğu düşünülmektedir.

Arjantin'de yüzey sularında pestisit kalıntısının araştırılmasına yönelik bir çalışmada en çok tespit edilen pestisitler Atrazin, Tebuconazole, Dietiltoluamid kimyasallarıdır (De Gerónimo vd. 2014). Bu çalışmada da en çok Endosülfan, Metribuzin, Permethrin, Malathion tespit edilmiştir. Başka bir çalışmada Sidney ve çevresindeki birkaç nehirden alınan su örneklerinde Acetamiprid, Clothianidin, İmidacloprid, Thiacloprid, Thiamethoxam araştırması yapılmıştır. Elde edilen sonuçların maksimum ve minimum değerleri $\mu \mathrm{g} / \mathrm{L}$ olarak sırasıyla $0,37-0,02 ; 0,12-0,02 ; 4,56-0,05 ; 1,37-0,02 ; 0,2-0,04$ olarak verilmiştir (Sánchez-Bayo ve Hyne 2013). Araştırması yapılan pestisitlerden Acetamiprid, İmidacloprid, Thiamethoxam bu çalışmada da yer almış fakat tespit edilememiştir.

Yasaklı aktif maddelerin bulunması ise yasaklı olduğu halde bu aktif maddelerin varlığı eskiye dayalı bir kirliliği akla getirmektedir. Yasaklı olmadığı dönemlerde kullanılmasıyla sediment ve toprakta birikim yapmış olabilirler. Yağmur suyu ile de taşınarak Alara Çayı'na taşınımı söz konusu olabilir. Tarımın yoğun olduğu alanlarda yer altı suları ile yüzeysel sulardaki pestisit kalıntısının karşılaştırılmasının yapıldığı bir çalışmada, yer altı sularında Endosülfan Alfa 0,78 $\mu \mathrm{g} / \mathrm{L}$; Chlorpyrifos $0,25 \mu \mathrm{g} / \mathrm{L}$; Parathion-methyl 0,09 $\mu \mathrm{g} / \mathrm{L}$ bulunurken, yüzeysel sularda Endosülfan Alfa ve Beta 0,42 $\mu \mathrm{g} / \mathrm{L}$; Dichlorvos 0,25 $\mu \mathrm{g} / \mathrm{L}$; Parathion-methyl 0,42 $\mu \mathrm{g} / \mathrm{L}$ bulunmuştur. Sonuç olarak yüzey suyunun yer altı suyundan daha kirli olduğu tespit edilmiştir (Lari vd. 2014). Bizim çalışmamızda olduğu gibi yasaklı pestisitlere burada da rastlanmıştır.

Alanya'daki çiftçi ve zirai ilaç satan firmalarla yapılan görüşmelerde belirtildiği üzere Alanya'da en çok mücadele edilen zararlılar kırmızı örümcek, beyazsinek, yaprak biti, trips ve yeşil kurttur. Dolayısıyla bu zararlılarla mücadelede kullanılan pestisitler bu bölgede fazlaca kullanılmaktadır. İmidacloprid, Cypermethrin, Pyriproxyfen, Chlorpyrifos, Malathion, Dimethoate, Deltamethrin, Acetamiprid, Abamectin, Spirotetramat kimyasalları, satışı çok yapılan zirai ilaçların aktif maddeleridir. Abamectin ve Spirotetramat dişındaki maddelerin hepsi bu çalışmada araştırılmıştır. Bu maddelerden; Cypermethrin 1,98 ile 13,37 $\mu \mathrm{g} / \mathrm{L}$; Deltamethrin 1,32 ile 1,52 $\mu \mathrm{g} / \mathrm{L}$; Malathion 1,47 ile 2,72 $\mu \mathrm{g} / \mathrm{L}$ arasinda değişmektedir.

Yapılan başka bir çalışmada sudaki pestisit kalıntılarının belirlenmesi için Quechers metodu modifiye edilerek valide edilmiştir. Bu çalışma için Malathion, Chlorpyrifos, Profenofos, Pyriproxyfen, Lambda- cyhalothrin, cypermethrinalpha aktif maddeleri seçilmiştir. Validasyon çalışmaları sonucunda LOD 0,28 ile 3,23 $\mu \mathrm{g} / \mathrm{L}$; LOQ 0,95 ile 10,78 $\mu \mathrm{g} / \mathrm{L}$ arasında çıkmıştır (AbdelGhani ve Hanafi 2016). Bu değerler bizim çalışmamızda LOD 0,23 ile 9,67 $\mu \mathrm{g} / \mathrm{L}$; LOQ ise bakılan pestisitlerin \%90'ında $10 \mu \mathrm{g} / \mathrm{L}$ çıkmıştır. \%10'luk bir kısmın LOQ değerleri $10 \mu \mathrm{g} / \mathrm{L}$ 'den büyüktür. Analizlerde kullanılan Quechers metodunun ölçüm limitleri, eser maddelerin tayini için yüksek kalmaktadır. Dolayısıyla Quechers metodunun, pestisit yoğunluğu fazla olan numunelerde uygulanması daha sağlıklı olacaktır.

Pestisit kalıntısının varlığının araştırıldığ 1 bu çalışmadan anlaşıldığı üzere tespit edilen bazı pestisitlerin konsantrasyonları her ne kadar tayin limitlerinin altında kalsa da Alara Çayı'nda pestisit kalıntısının varlığından söz edilebilmektedir. Sediment ve toprakta da pestisit taraması yapılırsa daha gerçekçi ve belirleyici bir sonuç elde edilebilecektir.

\section{Kaynaklar}

AbdelGhani S.B., Hanafi H.A., (2016), QuEChERS Method Combined with GC-MS for Pesticide Residue sDetermination in Water, Journal of Analytical Chemistry, 71 (5), 508-512.

Açar Ö., (2015), Pestisit analizleri eğitim notu, T.C Gıda Tarım ve Hayvancılık Bakanlığı Ulusal Referans Laboratuvarı Kalıntı/Pestisit Birimi, Ankara, 31ss.

Agarwal S.A., (2009), Pesticide Pollution, New Delhi: APH Publishing, 71ss.

Altınbilek D., Aydın A., Altındal M., (Ed.), (2002), Antalya havzası kirlilik araştırması raporu, T.C. Enerji ve Tabii Kaynaklar Bakanlığı Devlet Su İşleri Genel Müdürlüğü, Ankara, 150ss.

APHA (2012), Standard Methods for the examination of water and wastewater, 22th Edition, American Public Health Association Washington, USA.

Brondi S.H.G., de Macedo A.N., Vicente G.H.L., Nogueira A.R.A., (2011), Evaluation of the QuEChERS Method and Gas Chromatography-Mass Spectrometry for the Analysis Pesticide Residues in Water and Sediment, Bulletin of Environmental Contamination and Toxicology, 86(1), 18-22.

Burçak A.A., (2014), İlaç, alet ve toksikoloji araştırmaları çalışma grubu, http://www.tarim.gov.tr/TAGEM/Belgeler/Sunular, [Erişim 20 Haziran 2018]. 
Chakravarty S., (2014), World Agrochemical and Pesticide Market to Grow 8.7\% annually from 2014 to 2018 , https://www.marketresearchreports.com/blog/2014/01/06/world-agrochemical-and-pesticide-market-grow-87-annually-20142018, [Erişim 20 Haziran 2018].

De Gerónimo E., Aparicio V.C., Bárbaro S., Portocarrero R., Jaime S., Costa J.L., (2014), Presence of pesticides in surface water from four sub-basins in Argentina, Chemosphere, 107, 423-431.

Demirci Ö., (2013), Çeşitli pestisitlerin gamma ruskis chineffensis 'in antioksidan enzim sistemi ve bazı biyo belirteçler üzerine etkisi, Doktora Tezi, Dicle Üniversitesi, Diyarbakır.

Durdu B., (2018), Tarım açık alanlarında toprak kirliliğinin belirlenmesi, Yüksek Lisans Tezi, Aksaray Üniversitesi, Aksaray.

Durmuşoğlu E., Güngör Ö., (2015), Bitki koruma ürünleri ile ilgili son yıllarda çıkan yönetmelikler hakkında genel bir değerlendirme, Türkiye Ziraat Mühendisliği VIII. Teknik Kongresi, Ankara, Bildiriler Kitabı, Cilt 2, 713-726.

EC, (2016), Guidance document on analytical quality control and method validation procedures for pesticide residues and analysis in food and feed, European Commission Regulation, SANTE/10521/2016-EN ANNEX Rev. 1, http://ec.europa.eu/transparency/ regcomitology/index.cfm?do=Search.getPDF\&ds_id=45998\&version=4\&AttLang=en\&db_number=2\&docType=DRAFT_MEA SURE, [Erişim 19 Mart 2018].

Eurachem, (2014), The Fitness for Purpose of Analytical Methods, A Laboratory Guide to Method Validation and Related Topics 2st Ed., 70s, https://www.eurachem.org/images/stories/Guides/pdf/MV_guide_2nd_ed_EN.pdf, [Erişim 20 Haziran 2018].

FAO, (2003), International code of conduct on the distribution and use of pesticides, Food and Agriculture Organization of the United Nations, http://www.fao.org/3/y4544e/y4544e00.htm, [Erişim 25 Ekim 2007].

Gül, H., (2017), Türkiye'de Kullanılan Zirai İlaçların Sağlığa Etkileri, Tezsiz Yüksek Lisans Dönem Projesi, Nevşehir Hacı Bektaş Veli Üniversitesi, Nevşehir.

Güler Ç., Çobanoğlu Z., (1997), Pestisitler, T.C Sağlık Bakanlığı Çevre Sağlığı Temel Kaynak Dizisi, Ankara, 52s.

Katip A., (2019), Pestisit üretiminde atıksuların koagülasyon/flokülasyon prosesi ile geri kazanımının değerlendirilmesi, Doğal Afetler ve Çevre Dergisi, 5(1), 94-100.

Kurutaş E.B., Kılınç M., (2003), Pestisitlerin Biyolojik Sistemler Üzerine Etkisi, Arşiv 12:215, 215-228.

Lari S.Z., Khan N.A., Gandhi K.N., Meshram T.S., Thacker N.P., (2014), Comparison of pesticideresidues in surface water and ground water of agriculture intensiv areas, Journal of Environmental Health Science \& Engineering, 12(1), 11-18.

Lehotay S.J., (2007), Determination of pesticide residues in foods by acetonitrile extraction and partitioning with magnesium sulfate: collaborative study, Journal of AOAC International, 90(2), 485-520.

Mastalerz P., (2005), The true story of DDT, PCB, and Dioxin. Wroclaw, Wydawnic two Chemiczne, 93-9.

Öncüer C., (1995), Tarımsal zararlılarla savaş yöntemleri ve ilaçları, Ege Üniversitesi Basımevi, İzmir, 80s.

Resmi Gazete, (2015), Yüzeysel su kalitesi yönetimi yönetmeliğinde değişiklik yapılmasına dair yönetmelik, Resmi Gazete, Tarih: 15 Nisan 2015, Say1: 29327, http://www.resmigazete.gov.tr/eskiler/2015/04/20150415-18.htm, [Erişim 19 Mart 2018].

Sánchez-Bayo F., Hyne R.V., (2013), Detection and analysis of neonicotinoids in riverwaters - Development of a passive sampler for three commonly use dinsecticides, Chemosphere, 99, 143-151.

Schilz R, (2001), Comparison of spraydrift- andrunoff-relatedinput of azinphos-methylandendosulfan from fruitor chards into the Lourens River, South Africa, Chemosphere, 45, 543-551.

Tanabe S., (2004), POPs: Need for target research on high risk stage, Mar. Pollut. Bull., 48, 609-610.

Tekbaş Ö.F., İstanbulluoğlu H., Kakillioğlu T., (2010), Pestisitler ve toplum sağlığı, T.C Sağlık Bakanlığı Temel Sağlık Hizmetleri Genel Müdürlüğü, Ankara.

TS EN ISO 5667-3, (2013), Su kalitesi - Numune alma -Bölüm 3: Su numunelerinin muhafaza, taşıma ve depolanması için kılavuz, Türk Standartları Enstitüsü, Ankara.

TS ISO 5667-6, (2015), Su kalitesi - Numune alma - Bölüm 6 - Nehirlerden ve akarsulardan numune alma kılavuzu, Türk Standartları Enstitüsü, Ankara.

TÜBİTAK, (2013), Havza koruma eylem planlarının hazırlanması projesi Antalya havzası 5118601 (ÇTÜE.13.152) Proje Nihai Raporu, Türkiye Bilimsel ve Teknolojik Araştırma Kurumu Marmara Araştırma Merkezi Çevre ve Temiz Üretim Enstitüsü (TÜBİTAK MAM ÇTÜE), Kocaeli.

URL-1, (2018), https://www.tarim.gov.tr/GKGM/Menu/16/Projeler, [Erişim 19 Mart 2018].

URL-2, (2018), https://www.tarim.gov.tr/Konu/934/Yasaklanan-Bitki-Koruma-Urunleri-Aktif-Madde-Listesi, [Erişim 19 Mart 2018 ].

URL-3, (2018), https://www.sigmaaldrich.com/european-export.html, [Erişim 19 Mart 2018].

Villarroel M.J., Sancho E., Andreu-Moliner E., Ferrando M.D., (2009), Biochemical stress response in tetradifonexposed Daphniamagnaandits relationship to individual growth and reproduction, Science of The Total Environment, 407(21), 5537-5542.

Weber K., Goerke H., (2003), Persistent organic pollutants (POPs) in Antarctic fish: Levels, patterns, changes, Chemosphere, 53, 667-678.

Wesseling C., Corriols M., Bravo V., (2005), Acute pesticide poisonnig and pesticide registration in Central America. Toxicol. Appl. Pharm., 207, 697-705. 